\title{
Asymmetric Total Synthesis and Revision to the Relative Stereochemistry of the Taumycin A Macrocycle
}

Justine N. deGruyter and William A. Maio*

Supporting Information

Materials and Methods

Unless otherwise noted, reactions were performed in flame-dried glassware under an atmosphere of dry nitrogen. Reaction solvents $\left(\mathrm{CH}_{2} \mathrm{Cl}_{2}\right.$, THF, and $\left.\mathrm{Et}_{2} \mathrm{O}\right)$ were purified before use in a Glass Contour Solvent Purification System under a flow of dry nitrogen. All other solvents and reagents were purchased from Sigma-Aldrich and used as received, unless otherwise specified. Thin-layer chromatography (TLC) was performed using plates precoated with silica gel $60 \AA$ A-254 (250 $\mu \mathrm{m})$ purchased from Silicycle and visualized by UV light, KMnO4 or anisaldehyde stains, followed by heating. Silicycle SilicaFlash ${ }^{\circledR}$ P60 silica gel (particle size 40-63 $\mu \mathrm{m}$ ) was used for flash chromatography. Ozonolysis was conducted using a Weslbach T-408 Ozonator. ${ }^{1} \mathrm{H}$ and ${ }^{13} \mathrm{C}$ NMR spectra were recorded on a Varian Oxford 300 (operating at $300 \mathrm{MHz}$ and $75 \mathrm{MHz}$ respectively) or Varian Unity 400 (operating at $500 \mathrm{MHz}$ and $125 \mathrm{MHz}$, respectively), and are reported relative to residual solvent peak $\left(\delta 7.26\right.$ for ${ }^{1} \mathrm{H}$ and $\delta 77.0$ for ${ }^{13} \mathrm{C}$ in $\left.\mathrm{CDCl}_{3}\right)$. Data for ${ }^{1} \mathrm{H}$ NMR spectra are reported as follows: chemical shift $(\delta \mathrm{ppm})$ [multiplicity, coupling constant $(\mathrm{Hz})$, integration]. Spectra obtained are described using the following abbreviations: $\mathrm{s}=$ singlet, $\mathrm{d}$ $=$ doublet, $\mathrm{t}=$ triplet, $\mathrm{q}=$ quartet, $\mathrm{m}=$ multiplet. IR spectra were recorded on a Perkin Elmer Spectrum One FTIR Spectrometer and samples were prepared by evaporation from $\mathrm{CHCl}_{3}$ or $\mathrm{CH}_{2} \mathrm{Cl}_{2}$ on $\mathrm{NaCl}$ plates. High-resolution mass spectra were obtained through positive electrospray ionization on a Bruker 12 Tesla APEX -Qe FTICR-MS with and Apollo II ion source at the COSMIC Laboratory facility at Old Dominion University, VA. 
Experimental Procedures and Compound Characterization Data:

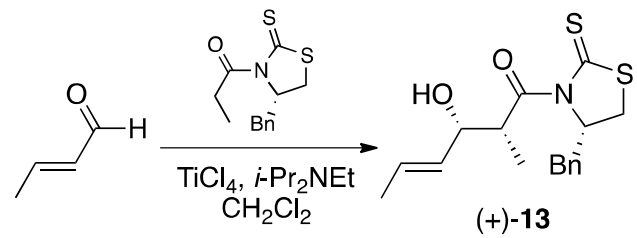

Thiazolidinethione (+)-13. Was prepared using the modified literature procedure of Crimmins and Chaudhary. ${ }^{1}$ A $1000 \mathrm{~mL}$ roundbottom flask was charged with 4-benzyl-3-propionyl-2thiazolidine-2-thione $(9.52 \mathrm{~g}, 35.9 \mathrm{mmol})$, dry $\mathrm{CH}_{2} \mathrm{Cl}_{2}(230 \mathrm{~mL})$, and cooled to $0{ }^{\circ} \mathrm{C}$. To this was added a freshly prepared $1.0 \mathrm{M} \mathrm{CH}_{2} \mathrm{Cl}_{2}$ solution of $\mathrm{TiCl}_{4}(35.9 \mathrm{~mL}, 35.9 \mathrm{mmol}, 1.0$ equiv.) dropwise over the course of about $10 \mathrm{~min}$, gradually turning the translucent yellow solution turbid yellow. After an additional 5 min of stirring, diisopropylethylamine (the Hünig base, $6.23 \mathrm{~mL}$, 35.9 mmol, 1.0 equiv.) was added drop wise, causing the reaction mixture to turn a deep red color. After $20 \mathrm{~min}$, the contents of the flask were cooled to $-78{ }^{\circ} \mathrm{C}$ and crotonaldehyde $(3.30$ $\mathrm{mL}, 39.5 \mathrm{mmol}, 1.1$ equiv.) was added neat at a rate of about one drop every two seconds. The reaction mixture was then allowed to stir at $-78{ }^{\circ} \mathrm{C}$ for $4.5 \mathrm{~h}$ before being warmed to room temperature over the course of $30 \mathrm{~min}$ and quenched with a half-saturated aqueous solution of $\mathrm{NH}_{4} \mathrm{Cl}$. The reaction mixture was then extracted with $\mathrm{CH}_{2} \mathrm{Cl}_{2}$, dried over $\mathrm{MgSO}_{4}$, filtered, and concentrated to afford crude thiazolidinethione, which was purified by flash column chromatography (3:1 hexanes:EtOAc) to afford $9.36 \mathrm{~g}(78 \%$ yield $)$ of $(+)-13$ as a thick yellow oil. ${ }^{1} \mathrm{H},{ }^{13} \mathrm{C}$ and optical rotation data was in full agreement with literature values. ${ }^{1}{ }^{1} \mathrm{H}$ NMR $(\delta \mathrm{ppm}$, $\left.\mathrm{CDCl}_{3}, 300 \mathrm{MHz}\right)$ 7.31-7.26 (m, 5H), 5.84-5.73 (m, 1H), 5.53 (dd, $\left.J=6.0,15.0 \mathrm{~Hz}, 1 \mathrm{H}\right), 5.43-$ $5.36(\mathrm{~m}, 1 \mathrm{H}), 4.83-4.75(\mathrm{~m}, 1 \mathrm{H}), 4.56-4.55(\mathrm{~m}, 1 \mathrm{H}), 3.37$ (dd, $J=7.2,11.4 \mathrm{~Hz}, 1 \mathrm{H}), 3.24$ (dd, $J=$ $3.9,13.2 \mathrm{~Hz}, 1 \mathrm{H}), 3.04(\mathrm{dd}, J=10.5,13.2 \mathrm{~Hz}, 1 \mathrm{H}), 2.48(\mathrm{~d}, J=11.4,1 \mathrm{H}), 2.74(\mathrm{~d}, J=2.7 \mathrm{~Hz}$, $1 \mathrm{H}), 1.73(\mathrm{dd}, J=0.9,6.3 \mathrm{~Hz}, 3 \mathrm{H}), 1.19(\mathrm{~d}, J=7.2 \mathrm{~Hz})$.

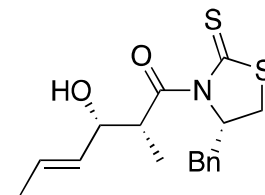

$(+)-13$

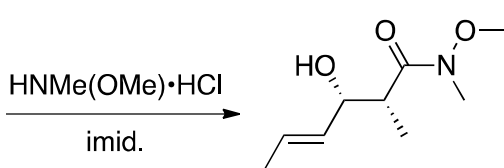

$(-)-14$

Weinreb Amide (-)-14. A solution of (+)-13 (3.65 g, $10.9 \mathrm{mmol})$ in dry $\mathrm{CH}_{2} \mathrm{Cl}_{2}(56 \mathrm{~mL})$ was sequentially treated with imidazole $(3.70 \mathrm{~g}, 54.4 \mathrm{mmol}, 5.0$ equiv. $)$ and $\mathrm{N}$, Odimethylhydroxylamine $\cdot \mathrm{HCl}$ (azeotroped 3x with toluene, $2.66 \mathrm{~g}, 27.2 \mathrm{mmol}, 2.5$ equiv.). The contents of the flask were then allowed to stir at room temperature overnight, gradually turning the yellow solution turbid white. The reaction was quenched with a saturated aqueous solution of $\mathrm{NH}_{4} \mathrm{Cl}$, extracted using $\mathrm{CH}_{2} \mathrm{Cl}_{2}$, dried over $\mathrm{MgSO}_{4}$, filtered, and concentrated. The crude Weinreb amide was purified by flash column chromatography (using the gradient 30:70 to 1:1 to 70:30 hexanes:EtOAc) to afford $1.85 \mathrm{~g}\left(91 \%\right.$ yield) of $(-)-14$ as a colorless oil. ${ }^{1} \mathrm{H},{ }^{13} \mathrm{C}$ was in agreement with literature values. The optical rotation value, however was of opposite sign to that reported by Kalesse for the same compound $\left\{[\boldsymbol{\alpha}]_{\boldsymbol{D}}^{\mathbf{2 4}}=-22.1\left(\mathrm{c}=2.25, \mathrm{CHCl}_{3}\right)\right.$, lit. $[\boldsymbol{\alpha}]_{\boldsymbol{D}}^{\mathbf{2 0}}=+24.8$

\footnotetext{
${ }^{1}$ Crimmins, M. T.; Chaudhary, K. Org. Lett. 2000, 2, 775-777.
} 
$\left.\left(\mathrm{c}=1.1, \mathrm{CHCl}_{3}\right)^{2}\right\}$. This discrepancy was resolved in two ways: (1) Mosher ester analysis of (-)14 revealed we had the proper alcohol stereoassignment, and (2) by the Kalesse laboratory repeating their initially reported data (personal communication). ${ }^{1} \mathrm{H}$ NMR ( $\delta \mathrm{ppm}, \mathrm{CDCl}_{3}, 300$ MHz) 5.82-5.70 (m, 1H), 5.54-5.45 (m, 1H), 4.38-4.35 (m, 1H), $3.70(\mathrm{~s}, 3 \mathrm{H}), 3.63$ (d, $J=3.0 \mathrm{~Hz}$, $1 \mathrm{H}), 3.20(\mathrm{~s}, 3 \mathrm{H}), 3.0-2.85$ (bs, 1H), 1.73-1.70 (m, 3H), $1.18(\mathrm{~d}, J=6.9 \mathrm{~Hz}, 3 \mathrm{H})$.

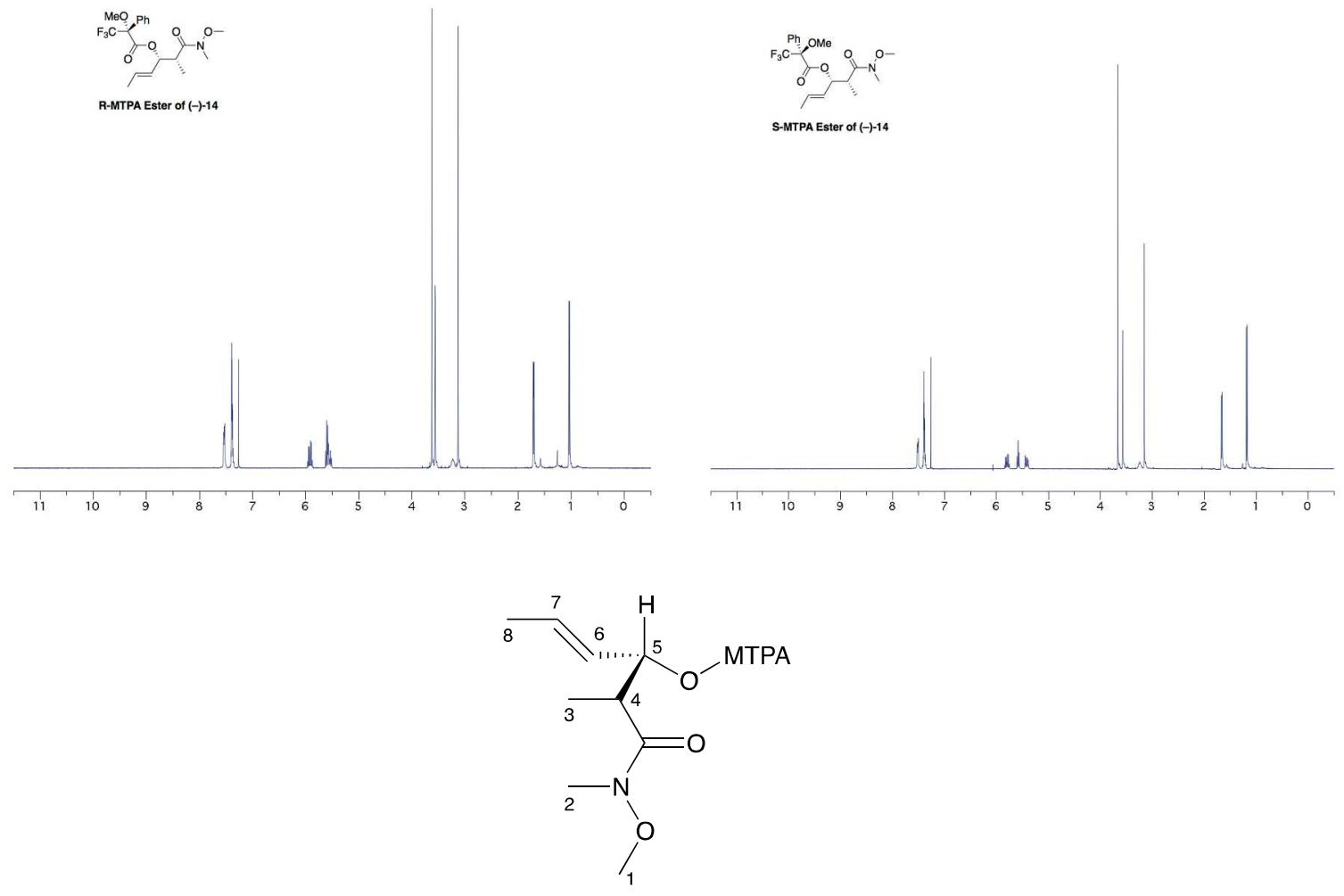

\begin{tabular}{|l|l|l|l|}
\hline & $\delta$ S-ester & $\delta$ R-ester & \multicolumn{1}{|c|}{$\Delta \delta(=\square \mathrm{S}-\square \square$} \\
$\mathrm{R})$
\end{tabular}

2 Bhatt, U.; Christmann, M.; Quitschalle, M.; Claus, E.; Kalesse, M. J. Org. Chem. 2001, 66, 1885-1893. 
${ }^{3}$ Hoye, T. R.; Jeffrey, C. S.; Shao, F. Nature Protocols, 2007, 2, 2451-2458.

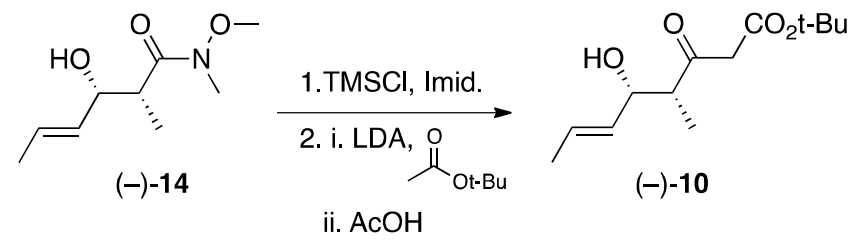

$\boldsymbol{\beta}$-Keto tert-Butyl Ester (-)-10. A $100 \mathrm{~mL}$ roundbottom flask was charged with amide (-)-14 (2.0 $\mathrm{g}, 10.7 \mathrm{mmol})$, dry $\mathrm{CH}_{2} \mathrm{Cl}_{2}(53 \mathrm{~mL})$, and imidazole $(1.45 \mathrm{~g}, 21.4 \mathrm{mmol}, 2.0$ equiv.). After the imidazole had completely dissolved, the flask was placed in a room temperature water bath before neat chlorotrimethylsilane $(2.03 \mathrm{~mL}, 16.0 \mathrm{mmol}, 1.5$ equiv.) was added dropwise over the course of about $10 \mathrm{~min}$. After an additional $20 \mathrm{~min}$ of stirring, the contents of the flask were quenched with a saturated aqueous solution of $\mathrm{NH}_{4} \mathrm{Cl}$, extracted with $\mathrm{CH}_{2} \mathrm{Cl}_{2}$, dried over $\mathrm{MgSO}_{4}$, filtered, and concentrated to afford crude TMS-protected amide which was taken directly on to the next step without any further purification.

To a solution of diisopropyl amine $\left(11.22 \mathrm{~mL}, 80.1 \mathrm{mml}, 7.5\right.$ equiv.) in dry $\mathrm{Et}_{2} \mathrm{O}(50 \mathrm{~mL})$ at $-78^{\circ} \mathrm{C}$ was added $n$-BuLi $(2.3 \mathrm{M}$ in hexanes, $32.1 \mathrm{~mL}, 74.7 \mathrm{mmol}, 7.0$ equiv.) dropwise. After stirring for $15 \mathrm{~min}$, tert-butyl acetate $\left(10.24 \mathrm{~mL}, 75.8 \mathrm{mmol}, 7.1\right.$ equiv.) in dry $\mathrm{Et}_{2} \mathrm{O}(50 \mathrm{~mL})$ was slowly added via cannula. After an additional $15 \mathrm{~min}$ of stirring, TMS-protected amide $[2.77 \mathrm{~g}$ (assumed 100\% yield from the first step), $10.7 \mathrm{mmol}, 1$ equiv.] in dry $\mathrm{Et}_{2} \mathrm{O}(50 \mathrm{~mL}$ ) was slowly added via cannula. The reaction mixture was immediately taken out of the $-78^{\circ} \mathrm{C}$ bath and allowed to warm to room temperature over the course of $3 \mathrm{~h}$ before being poured into a separatory funnel containing a saturated aqueous solution of $\mathrm{NH}_{4} \mathrm{Cl}$. After the vigorous bubbling had subsided, the contents of the separatory funnel were extracted using $\mathrm{Et}_{2} \mathrm{O}$, washed with brine, dried over $\mathrm{MgSO}_{4}$, filtered, and concentrated. The crude trimethylsiloxy-tert-butyl ester was then dissolved in methanol $(150 \mathrm{~mL})$, cooled to $0{ }^{\circ} \mathrm{C}$, and treated with $\mathrm{AcOH}(30 \mathrm{~mL})$ dropwise. After TLC analysis had revealed the complete cleavage of the silyl ether (ca. $4 \mathrm{~h}$ ), the contents of the flask were concentrated in vacuo, then dissolved in ethyl acetate, extracted using a saturated aqueous solution of $\mathrm{NaHCO}_{3}$, dried over $\mathrm{MgSO}_{4}$, filtered, and concentrated to afford the crude alcohol which was purified by flash column chromatography (using a tall bed of silica, 4:1 hexanes:EtOAc) to afford $2.12 \mathrm{~g}$ (82\% yield over two steps) of (-)-10 as a colorless oil. $[\boldsymbol{\alpha}]_{\boldsymbol{D}}^{\mathbf{2 4}}=-34.1\left(\mathrm{c}=1.75, \mathrm{CHCl}_{3}\right)$; IR (neat, thin film) $\vee 2987,2939,1734,1713,1644,1368$, $1252,1155,845 \mathrm{~cm}^{-1} ;{ }^{1} \mathrm{H} \mathrm{NMR}\left(\delta \mathrm{ppm}, \mathrm{CDCl}_{3}, 300 \mathrm{MHz}\right.$, as a mixture of keto and enol forms) $12.45(\mathrm{~s}, 0.2 \mathrm{H}), 5.79-5.67(\mathrm{~m}, 1 \mathrm{H}), 5.50-5.41(\mathrm{~m}, 1 \mathrm{H}), 4.93(\mathrm{~s}, 0.2 \mathrm{H}), 4.40-4.36(\mathrm{~m}, 1 \mathrm{H}), 4.29-$ $4.25(\mathrm{~m}, 0.2 \mathrm{H}), 3.45(\mathrm{~s}, 2 \mathrm{H}), 2.87-2.78(\mathrm{~m}, 1 \mathrm{H}), 1.71(\mathrm{dq}, J=0.9,6.6 \mathrm{~Hz}, 3 \mathrm{H}), 1.47(\mathrm{~s}, 9 \mathrm{H}), 1.13$ $(\mathrm{d}, J=7.2 \mathrm{~Hz}, 3 \mathrm{H}) ;{ }^{13} \mathrm{C} \mathrm{NMR}\left(\delta \mathrm{ppm}, \mathrm{CDCl}_{3}, 400 \mathrm{MHz}\right) 207.0,166.5,130.2,128.4,82.0,72.8$, $51.3,50.2,27.9,17.7,10.7$; note: we were not able to obtain HRMS data for (-)-10, however all subsequent compounds derived from this alcohol are mass accurate (vide infra).

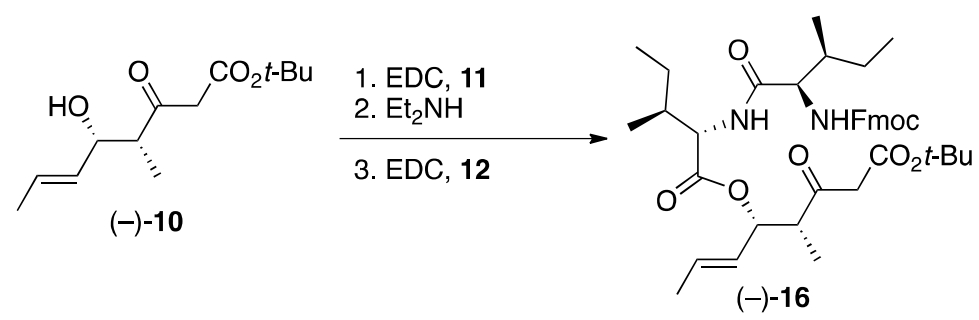


Fmoc-protected dipeptide (-)-16. Was prepared in three sequential synthetic operations. Alcohol (-)-10 (0.092 g, $0.38 \mathrm{mmol}$ ), Fmoc-ile-OH (11 $0.335 \mathrm{~g}, 0.95 \mathrm{mmol}, 2.5$ equiv.), and DMAP $(0.231 \mathrm{~g}, 0.95 \mathrm{mmol}, 1.9 \mathrm{mmol}, 5$ equiv. $)$ were dissolved in dry THF $(25 \mathrm{~mL})$ and cooled to $0{ }^{\circ} \mathrm{C}$ before being treated with EDC $(0.231 \mathrm{~g}, 1.9 \mathrm{mmol}, 5$ equiv. $)$ in three portions. After being allowed to stir for $20 \mathrm{~min}$, the contents of the flask were allowed to warm to $\mathrm{rt}$ and stir for an additional $2 \mathrm{~h}$ before being diluted with $\mathrm{Et}_{2} \mathrm{O}$, and added to a separatory funnel and washed successively with a $5 \%$ aqueous solution of citric acid, a $10 \%$ aqueous solution of $\mathrm{NaHCO}_{3}$, and brine. The organic layer was then dried over $\mathrm{MgSO}_{4}$, filtered, and concentrated. At this stage, we have found that it is often of sufficient purity to be taken on to the next step without further purification.

The crude monopeptide was dissolved in wet $\mathrm{MeCN}(30 \mathrm{~mL})$ and cooled to $0{ }^{\circ} \mathrm{C}$ before being treated with diethylamine $(0.78 \mathrm{~mL}, 6.0 \mathrm{mmol}, 20$ equiv. $)$ in a single portion. After being allowed to warm to $\mathrm{rt}$ and stir $2 \mathrm{hr}$, TLC analysis indicated the complete consumption of starting material, the contents of the flask were concentrated and taken directly on to the next step without any further purification.

The free amine, Fmoc-D-allo-ile-OH (12 0.335 g, 0.95 mmol, 2.5 equiv.), and DMAP (0.231 g, $0.95 \mathrm{mmol}, 1.9 \mathrm{mmol}, 5$ equiv.) were dissolved in dry THF $(25 \mathrm{~mL})$ and cooled to $0{ }^{\circ} \mathrm{C}$ before being treated with $\operatorname{EDC}(0.231 \mathrm{~g}, 1.9 \mathrm{mmol}, 5$ equiv. $)$ in three portions. After being allowed to stir for $20 \mathrm{~min}$, the contents of the flask were allowed to warm to rt and stir for an additional $2 \mathrm{~h}$ before being diluted with $\mathrm{Et}_{2} \mathrm{O}$, and added to a separatory funnel and washed successively with a $5 \%$ aqueous solution of citric acid, a $10 \%$ aqueous solution of $\mathrm{NaHCO}_{3}$, and brine. The organic layer was then dried over $\mathrm{MgSO}_{4}$, filtered, and concentrated. The crude Fmoc-protected dipeptide was purified by flash column chromatography (using a short bed of silica, $4: 1$ hexanes:EtOAc) to afford $0.167 \mathrm{~g}(64 \%)$ of $(-)-\mathbf{1 6}$ as an amorphous white solid. $[\boldsymbol{\alpha}]_{\boldsymbol{D}}^{\mathbf{2 4}}=-8.8\left(\mathrm{c}=0.6, \mathrm{CHCl}_{3}\right)$; IR (neat, thin film) $\vee 3339,2974,2939,1726,1658,1520,1458,1238,1148,742 \mathrm{~cm}^{-1} ;{ }^{1} \mathrm{H}$ NMR $(\delta$ $\mathrm{ppm}, \mathrm{CDCl}_{3}, 300 \mathrm{MHz}$, note: the spectrum is broad as a result of the compound exisiting as a mixture of keto and enol forms and rotational isomers $) 12.4(\mathrm{~s}, 0.4 \mathrm{H}), 7.68(\mathrm{~d}, J=7.5 \mathrm{~Hz}, 2 \mathrm{H})$, $7.52(\mathrm{~d}, J=7.2 \mathrm{~Hz}, 2 \mathrm{H}), 7.32(\mathrm{t}, J=7.2 \mathrm{~Hz}, 2 \mathrm{H}), 7.20(\mathrm{t}, J=7.5 \mathrm{~Hz}, 2 \mathrm{H}), 6.54(\mathrm{~d}, J=8.1 \mathrm{~Hz}$, $1 \mathrm{H}), 6.42(\mathrm{~d}, J=8.4 \mathrm{~Hz}, 1 \mathrm{H}), 5.742-5.61(\mathrm{~m}, 1 \mathrm{H}), 5.49-5.23(\mathrm{~m}, 3 \mathrm{H}), 4.83(\mathrm{~s}, 0.3 \mathrm{H}), 4.67-4.59$ (m, 0.4H), $4.53(\mathrm{dd}, J=4.5,8.4 \mathrm{~Hz}, 1 \mathrm{H}), 4.39-4.11(\mathrm{~m}, 4 \mathrm{H}), 3.40-3.28(\mathrm{~m}, 2 \mathrm{H}), 2.92-2.83(\mathrm{~m}$, $1 \mathrm{H}), 2.46-2.37(\mathrm{~m}, 0.4 \mathrm{H}), 1.95-1.75(\mathrm{~m}, 2 \mathrm{H}), 1.59(\mathrm{dd}, J=1.2,6.6 \mathrm{~Hz}, 3 \mathrm{H}), 1.38(\mathrm{~s}, 9 \mathrm{H}), 1.04(\mathrm{~d}$, $J=6.9 \mathrm{~Hz}, 3 \mathrm{H}), 0.92-0.71(\mathrm{~m}, 13 \mathrm{H}) ;{ }^{13} \mathrm{C} \mathrm{NMR}\left(\delta \mathrm{ppm}, \mathrm{CDCl}_{3}, 400 \mathrm{MHz}, \underline{\text { note }}\right.$ : the compound exists as a mixture of keto and enol forms and rotational isomers) 203.3, 177.1, 177.2, 170.4, 166.2, 143.7, 141.2, 128.9, 127.6, 127.0, 125.9, 125.0, 119.9, 88.7, 82.1, 81.0, 75.8, 67.0, 56.8, $50.2,49.7,47.2,37.8,37.6,28.2,27.9,26.2,24.8,17.6,15.5,14.2,11.6,11.5,11.4$; HRMS $m / z$ calc'd for $\mathrm{C}_{40} \mathrm{H}_{54} \mathrm{~N}_{2} \mathrm{O}_{8} \mathrm{Na}$ [M+Na]: 713.3777, found 713.3763.
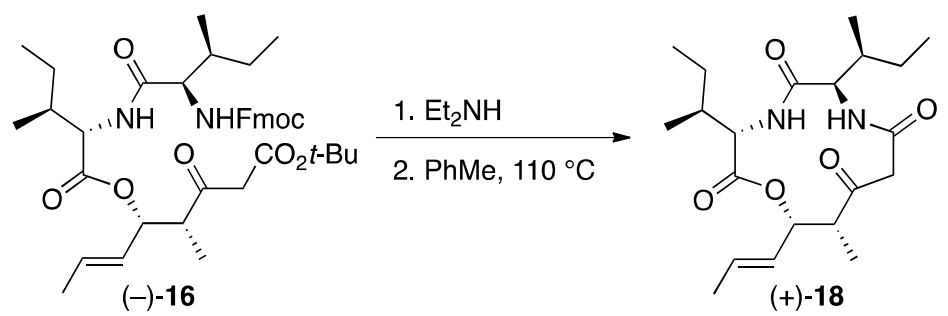

Macrocycle (+)-18. Fmoc-protected dipeptide (-)-16 (0.100 g, $0.15 \mathrm{mmol})$ was dissolved in wet $\mathrm{MeCN}(30 \mathrm{~mL})$ and cooled to $0{ }^{\circ} \mathrm{C}$ before being treated with diethylamine $(0.300 \mathrm{~mL}, 3.0 \mathrm{mmol}$, 20 equiv.) in a single portion. After being allowed to warm to $\mathrm{rt}$ and stir $2 \mathrm{hr}$, TLC analysis 
indicated the complete consumption of starting material, the contents of the flask were concentrated and azeotroped with toluene three times before being taken directly on to the next step without any further purification.

The free amine was dissolved in freshly distilled toluene $(50 \mathrm{~mL})$ and then gradually heated to a gentle reflux. After $2 \mathrm{~h}$, the flask was allowed to cool to room temperature and its contents concentrated. The crude macrocycle was purified by flash column chromatography $(70: 30$ hexanes:EtOAc) to afford $0.039 \mathrm{~g}(68 \%)$ of $(+)-17$ as an amorphous white solid. $[\boldsymbol{\alpha}]_{\boldsymbol{D}}^{\mathbf{2 4}}=+93.9$ $\left(\mathrm{c}=0.4, \mathrm{CHCl}_{3}\right) \mathrm{IR}$ (neat, thin film) v 3294, 2956, 2925, 2875, 1723, 1642, 1530, 1455, $1244 \mathrm{~cm}^{-}$ ${ }^{1}$; ${ }^{1} \mathrm{H}$ NMR $\left(\delta \mathrm{ppm}, \mathrm{CDCl}_{3}, 300 \mathrm{MHz}\right) 6.87(\mathrm{~d}, J=9.6 \mathrm{~Hz}, 1 \mathrm{H}), 6.65(\mathrm{~d}, J=9.6 \mathrm{~Hz}, 1 \mathrm{H}), 5.86-5.7$ $(\mathrm{m}, 1 \mathrm{H}), 5.59-5.50(\mathrm{~m}, 1 \mathrm{H}), 5.17(\mathrm{dd}, J=3.9,8.7 \mathrm{~Hz}, 1 \mathrm{H}), 4.25-4.18(\mathrm{~m}, 2 \mathrm{H}), 3.52(\mathrm{~d}, J=10.5$ $\mathrm{Hz}, 1 \mathrm{H}), 3.40(\mathrm{~d}, J=10.8 \mathrm{~Hz}, 1 \mathrm{H}), 3.10-3.02(\mathrm{~m}, 1 \mathrm{H}), 2.05-1.95(\mathrm{~m}, 1 \mathrm{H}), 1.71(\mathrm{dd}, J=1.5,6.6$ $\mathrm{Hz}, 3 \mathrm{H}), 1.52-1.34(\mathrm{~m}, 2 \mathrm{H}), 1.21-1.11(\mathrm{~m}, 1 \mathrm{H}) 1.12(\mathrm{~d}, J=7.2 \mathrm{~Hz}, 3 \mathrm{H}), 0.99-0.85(\mathrm{~m}, 12 \mathrm{H}) ;{ }^{13} \mathrm{C}$ $\operatorname{NMR}\left(\delta \mathrm{ppm}, \mathrm{CDCl}_{3}, 400 \mathrm{MHz}\right) 204.4,171.8,169.2,165.4,133.4,124.7,78.3,58.2,57.9,53.7$, $48.1,36.5,32.7,26.5,25.2,17.7,15.6,14.6,13.9,11.3,11.1$; HRMS $m / z$ calc'd for $\mathrm{C}_{21} \mathrm{H}_{34} \mathrm{~N}_{2} \mathrm{O}_{5} \mathrm{Na}[\mathrm{M}+\mathrm{Na}]:$ 417.23599, found 417.23593.

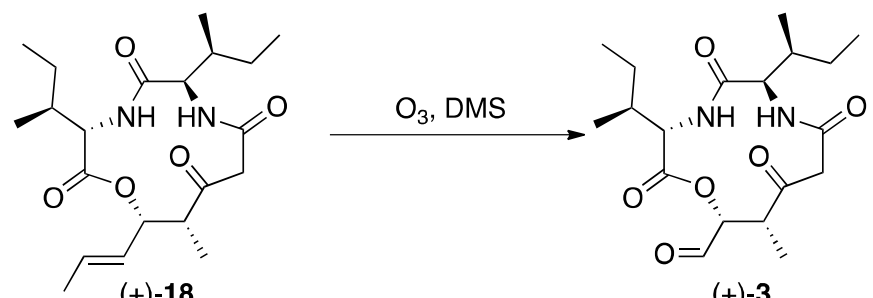

$(+)-18$

$(+)-3$

Taumycin Aldehyde (+)-3. Macrocycle (+)-17 (0.012 g, $0.030 \mathrm{mmol})$ was transferred to a twonecked flask using about $5 \mathrm{~mL}$ of wet $\mathrm{CH}_{2} \mathrm{Cl}_{2}$. A gas adaptor was then placed in one neck with a short plastic tube venting into an aqueous solution of potassium iodide. The second neck was fitted with a thermometer adaptor through which a glass pipette was inserted as a means for ozone to be bubbled into solution. The flask was cooled to $-78{ }^{\circ} \mathrm{C}$ and treated with ozone until we observed a persistent blue color, at which time the ozone generator was switched off and pure oxygen was allowed to bubble into solution until the blue color had dissipated. The reaction mixture was then quenched with dimethyl sulfide $(1 \mathrm{~mL})$ and allowed to slowly warm to room temperature and stir overnight. The contents of the flask were then washed with brine, dried over $\mathrm{MgSO}_{4}$, filtered, and concentrated to afford $0.009 \mathrm{~g} \mathrm{(81 \% )}$ of aldehyde (+)-3 as an amorphous white solid. $[\boldsymbol{\alpha}]_{\boldsymbol{D}}^{\mathbf{2 3}}=+134.3\left(\mathrm{c}=0.5, \mathrm{CHCl}_{3}\right)$; IR (neat, thin film) $\vee 3308,2956,2923,2874$, $2857,1750,1720,1665,1646,1528,1465,1383,1237 \mathrm{~cm}^{-1} ;{ }^{1} \mathrm{H}$ NMR $\left(\delta \mathrm{ppm}, \mathrm{CDCl}_{3}, 300 \mathrm{MHz}\right)$ $9.52(\mathrm{~s}, 1 \mathrm{H}), 6.61(\mathrm{~d}, J=9 \mathrm{~Hz}, 1 \mathrm{H}), 6.28(\mathrm{~d}, J=9 \mathrm{~Hz}, 1 \mathrm{H}), 5.00(\mathrm{~d}, J=3.9 \mathrm{~Hz}, 1 \mathrm{H}), 4.33(\mathrm{dd}, J=$ $5.7,9 \mathrm{~Hz}, 1 \mathrm{H}), 4.71(\mathrm{t}, J=10.5 \mathrm{~Hz}, 2 \mathrm{H}), 3.59(\mathrm{~d}, J=10.2 \mathrm{~Hz}, 1 \mathrm{H}), 3.45(\mathrm{~d}, J=10.2 \mathrm{~Hz}, 1 \mathrm{H})$, $3.27-3.19(\mathrm{~m}, 2 \mathrm{H}), 2.70-1.87(\mathrm{~m}, 2 \mathrm{H}), 1.39(\mathrm{~d}, J=7.2 \mathrm{~Hz}, 3 \mathrm{H}), 1.40-0.91(\mathrm{~m}, 12 \mathrm{H}) ;{ }^{13} \mathrm{C} \mathrm{NMR}(\delta$ ppm, $\left.\mathrm{CDCl}_{3}, 400 \mathrm{MHz}\right)$ 203.7, 195.1, 171.8, 169.3, 164.4, 79.1, 58.6, 57.9, 52.4, 47.6, 36.1, 32.9, 29.7, 26.3, 25.3, 15.6, 14.7, 12.7, 11.3, 11.0; HRMS $m / z$ calc'd for $\mathrm{C}_{19} \mathrm{H}_{30} \mathrm{~N}_{2} \mathrm{O}_{6} \mathrm{Na}[\mathrm{M}+\mathrm{Na}]$ : 405.19961, found 405.19960. 

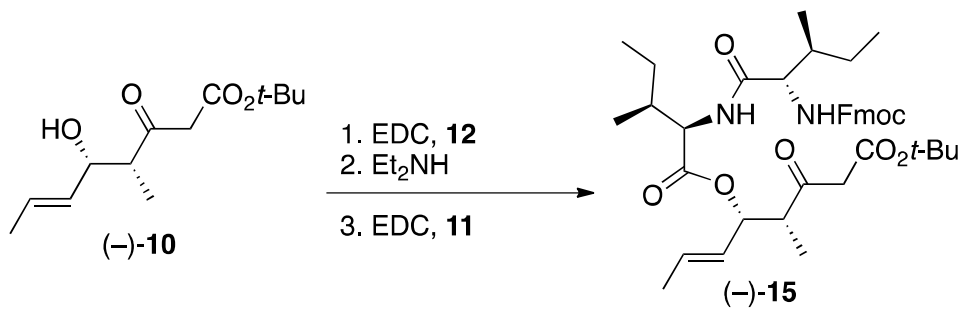

Fmoc-protected dipeptide (-)-15. Was prepared in a similar manner to Fmoc-protected dipeptide $(-)-16$ by reversing the order of amino acids (cf. first Fmoc-D-allo-ile-OH and then Fmoc-L-ile$\mathrm{OH}) .[\boldsymbol{\alpha}]_{\boldsymbol{D}}^{\mathbf{2 4}}=-7.8\left(\mathrm{c}=1.0, \mathrm{CHCl}_{3}\right)$; IR (neat, thin film) $v 3313,2966,2937,2877,1712,1664$, $1533,1449,1246,1151,738 \mathrm{~cm}^{-1} ;{ }^{1} \mathrm{H} \mathrm{NMR}\left(\delta \mathrm{ppm}, \mathrm{CDCl}_{3}, 300 \mathrm{MHz}\right.$, note: the spectrum is broad as a result of the compound exisiting as a mixture of keto and enol forms and rotational isomers) $12.17(\mathrm{~s}, 0.4 \mathrm{H}), 7.65(\mathrm{~d}, J=7.5 \mathrm{~Hz}, 2 \mathrm{H}), 7.50(\mathrm{~d}, J=7.2 \mathrm{~Hz}, 2 \mathrm{H}), 7.28(\mathrm{t}, J=7.2 \mathrm{~Hz}$, $2 \mathrm{H}), 7.20(\mathrm{t}, J=7.5 \mathrm{~Hz}, 2 \mathrm{H}), 6.65(\mathrm{~d}, 8.4 \mathrm{~Hz}, 1 \mathrm{H}) ; 5.71-5.60(\mathrm{~m}, 1 \mathrm{H}), 5.52(\mathrm{~d}, J=8.7 \mathrm{~Hz}, 1 \mathrm{H})$, $5.37-5.22(\mathrm{~m}, 2 \mathrm{H}), 4.81(\mathrm{~s}, 0.4 \mathrm{H}), 4.62(\mathrm{dd}, J=3.9,8.7 \mathrm{~Hz}, 1 \mathrm{H}), 4.34-4.24(\mathrm{~m}, 2 \mathrm{H}), 4.12(\mathrm{t}, J=$ $6.9 \mathrm{~Hz}, 2 \mathrm{H}), 3.40-3.27(\mathrm{~m}, 2 \mathrm{H}), 2.91-2.83(\mathrm{~m}, 1 \mathrm{H}), 1.92-1.75(\mathrm{~m}, 2 \mathrm{H}), 1.55(\mathrm{~d}, J=6 \mathrm{~Hz}, 3 \mathrm{H})$, $1.36(\mathrm{~s}, 9 \mathrm{H}), 1.17-0.98(\mathrm{~m}, 1 \mathrm{H}), 1.00(\mathrm{~d}, J=6.9 \mathrm{~Hz}, 3 \mathrm{H}), 0.88-0.72(\mathrm{~m}, 12 \mathrm{H}) ;{ }^{13} \mathrm{C} \mathrm{NMR}(\delta \mathrm{ppm}$, $\mathrm{CDCl}_{3}, 400 \mathrm{MHz}$, note: the compound exists as a mixture of keto and enol forms and rotational isomers) 203.6, 172.5, 171.2, 170.7, 166.3, 156.1, 156.0, 143.8, 143.6, 141.1, 132.4, 127.5, 126.9, $125.4,125.0,119.8,81.9,76.5,66.9,66.8,59.6,58.2,55.1,52.0,50.6,49.4,47.1,47.0,37.8$, $37.5,28.1,27.8,26.1,24.9,24.5,17.6,15.4,15.3,14.5,12.2,11.6,11.42,11.38$; HRMS $m / z$ calc'd for $\mathrm{C}_{40} \mathrm{H}_{54} \mathrm{~N}_{2} \mathrm{O}_{8} \mathrm{Na}[\mathrm{M}+\mathrm{Na}]$ : 713.3777, found 713.3765.
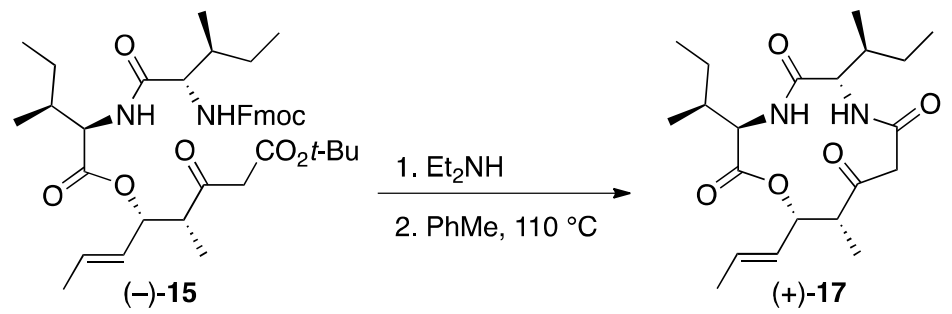

Macrocycle (+)-17. Was prepared in a similar manner to macrocycle $(+)-\mathbf{1 8} .[\boldsymbol{\alpha}]_{\boldsymbol{D}}^{23}=+73.5(\mathrm{c}=$ $0.8, \mathrm{CHCl}_{3}$ ); IR (neat, thin film) v 3281, 2959, 2930, 2871, 1738, 1720, 1650, 1537, 1455, 1377, $1199,980 \mathrm{~cm}^{-1} ;{ }^{1} \mathrm{H}$ NMR $\left(\delta \mathrm{ppm}, \mathrm{CDCl}_{3}, 300 \mathrm{MHz}\right) 6.59(\mathrm{~d}, \mathrm{~J}=10.2,1 \mathrm{H}), 6.54(\mathrm{~d}, \mathrm{~J}=9.6,1 \mathrm{H})$, 5.80-5.68 (m, 1H), 5.58-5.50 (m, 1H), $5.02(\mathrm{dd}, \mathrm{J}=4.5,8.7 \mathrm{~Hz}, 1 \mathrm{H}), 4.63(\mathrm{dd}, \mathrm{J}=3.3,10.2 \mathrm{~Hz}$, $1 \mathrm{H}), 4.12(\mathrm{t}, \mathrm{J}=10.5 \mathrm{~Hz}, 1 \mathrm{H}), 3.58(\mathrm{~d}, \mathrm{~J}=10.5 \mathrm{~Hz}, 1 \mathrm{H}), 3.48-3.42(\mathrm{~m}, 1 \mathrm{H}), 3.28(\mathrm{~d}, \mathrm{~J}=11.1 \mathrm{~Hz}$, $1 \mathrm{H}), 2.20-2.12(\mathrm{~m}, 1 \mathrm{H}), 2.06-1.97(\mathrm{~m}, 1 \mathrm{H}), 1.72(\mathrm{dd}, \mathrm{J}=1.5,6.3 \mathrm{~Hz}, 3 \mathrm{H}), 1.73-1.71(\mathrm{~m}, 1 \mathrm{H})$, $1.37-1.12(\mathrm{~m}, 4 \mathrm{H}), 1.03(\mathrm{~d}, \mathrm{~J}=7.2 \mathrm{~Hz}, 3 \mathrm{H}), 0.96-0.86(\mathrm{~m}, 9 \mathrm{H}) ;{ }^{13} \mathrm{C} \mathrm{NMR}\left(\delta \mathrm{ppm}, \mathrm{CDCl}_{3}, 400\right.$ MHz) 206.8, 170.9, 170.5, 165.5, 133.3, 124.3, 79.3, 58.2, 55.8, 55.1, 46.9, 35.5, 32.4, 26.5, 24.7, $17.9,16.0,14.7,14.2,11.8,10.5$; HRMS $m / z$ calc'd for $\mathrm{C}_{21} \mathrm{H}_{34} \mathrm{~N}_{2} \mathrm{O}_{5} \mathrm{Na}[\mathrm{M}+\mathrm{Na}]: 417.23599$, found 417.23591. 


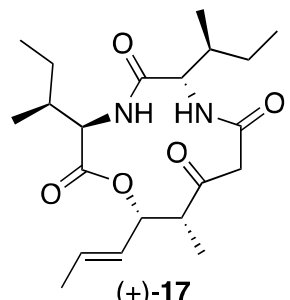

$(+)-17$

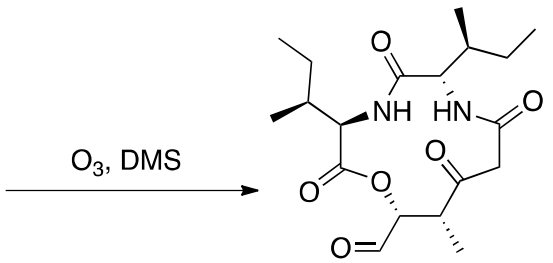

$(+)-19$

Aldehyde (+)-19. Was prepared in a similar manner to aldehyde (+)-3. note: The ${ }^{1} \mathrm{H}$ NMR shows minor contamination from an unidentified diastereomer that was formed during the ozonolysis operation. Any attempt at purification led to larger amounts of this impurity. The yield reported in the manuscript has been adjusted to reflect the major diastereomer only. $[\boldsymbol{\alpha}]_{\boldsymbol{D}}^{23}=+71.8(\mathrm{c}=0.7$, $\mathrm{CHCl}_{3}$ ); IR (neat, thin film) $\vee 3302,2962,2923,2874,2857,1742,1723,1649,1531 \mathrm{~cm}^{-1} ;{ }^{1} \mathrm{H}$ $\operatorname{NMR}\left(\delta \mathrm{ppm}, \mathrm{CDCl}_{3}, 300 \mathrm{MHz}\right) 9.40(\mathrm{~s}, 1 \mathrm{H}), 6.97(\mathrm{~d}, \mathrm{~J}=9.3 \mathrm{~Hz}, 1 \mathrm{H}), 6.40(\mathrm{~d}, \mathrm{~J}=9.9 \mathrm{~Hz}, 1 \mathrm{H})$, 4.83-4.77 (m, 1H), 4.58 (dd, J = 1.8, $4.5 \mathrm{~Hz}, 1 \mathrm{H}), 4.13(\mathrm{dd}, \mathrm{J}=9.3,10.8 \mathrm{~Hz}, 1 \mathrm{H}), 3.82-3.73$ (m, $1 \mathrm{H}), 3.63(\mathrm{~d}, \mathrm{~J}=10.2 \mathrm{~Hz}, 1 \mathrm{H}), 3.26(\mathrm{~d}, \mathrm{~J}=10.2 \mathrm{~Hz}, 1 \mathrm{H}), 2.19-2.10(\mathrm{~m}, 1 \mathrm{H}), 2.07-1.97(\mathrm{~m}, 1 \mathrm{H})$, $1.75-1.60(\mathrm{~m}, 4 \mathrm{H}), 1.41-1.12(\mathrm{~m}, 5 \mathrm{H}), 0.95-0.87(\mathrm{~m}, 12 \mathrm{H}) ;{ }^{13} \mathrm{C} \mathrm{NMR}\left(\delta \mathrm{ppm}, \mathrm{CDCl}_{3}, 400 \mathrm{MHz}\right)$ 206.1, 196.5, 171.1, 170.7, 164.7, 78.6, 58.5, 55.1, 54.3, 48.2, 35.8, 32.5, 29.7, 26.3, 24.5, 15.8, 14.7, 112.6, 11.5, 10.3; HRMS m/z calc'd for $\mathrm{C}_{19} \mathrm{H}_{30} \mathrm{~N}_{2} \mathrm{O}_{6} \mathrm{Na}[\mathrm{M}+\mathrm{Na}]$ : 405.19961, found 405.19969 . 

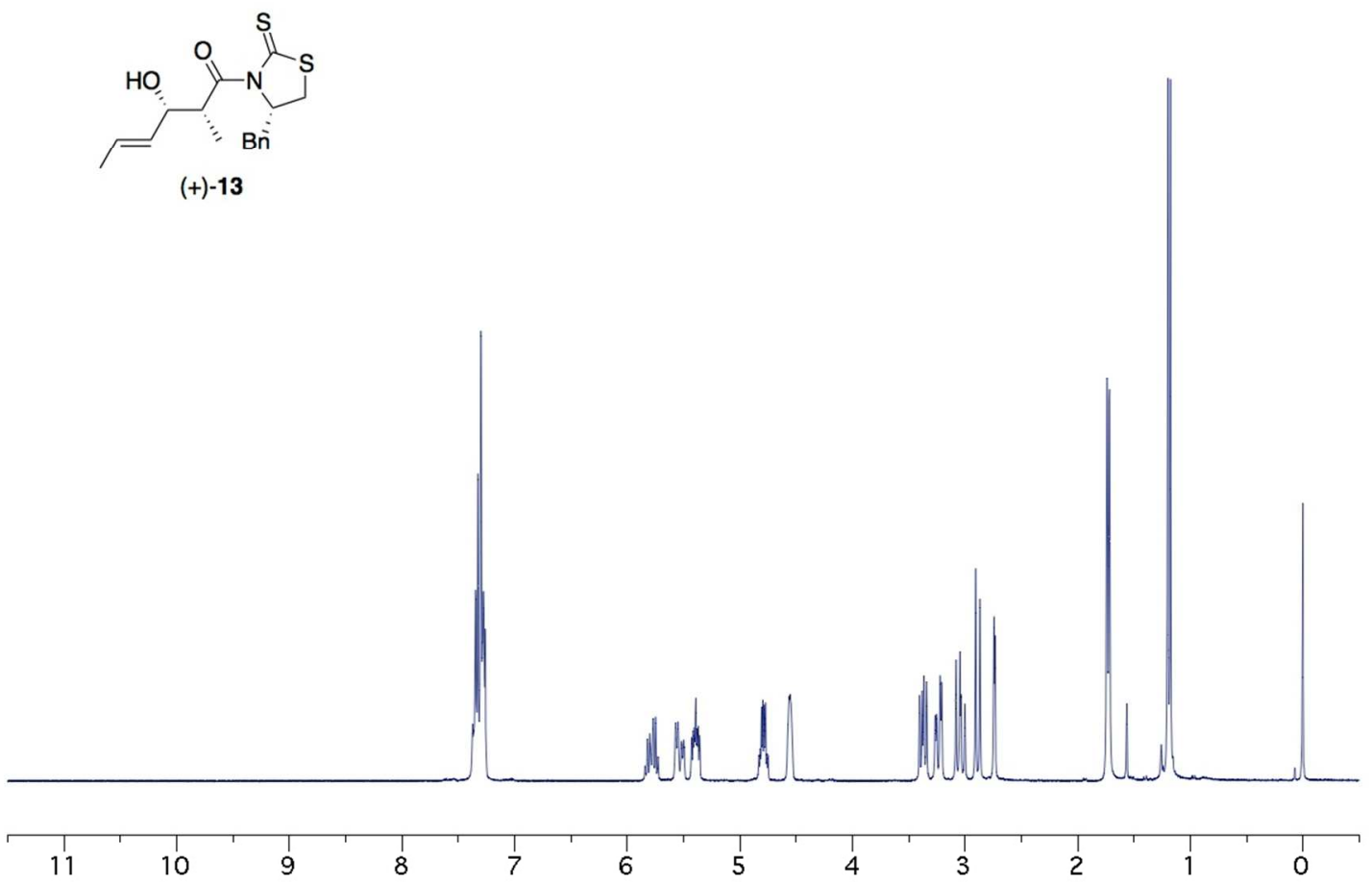


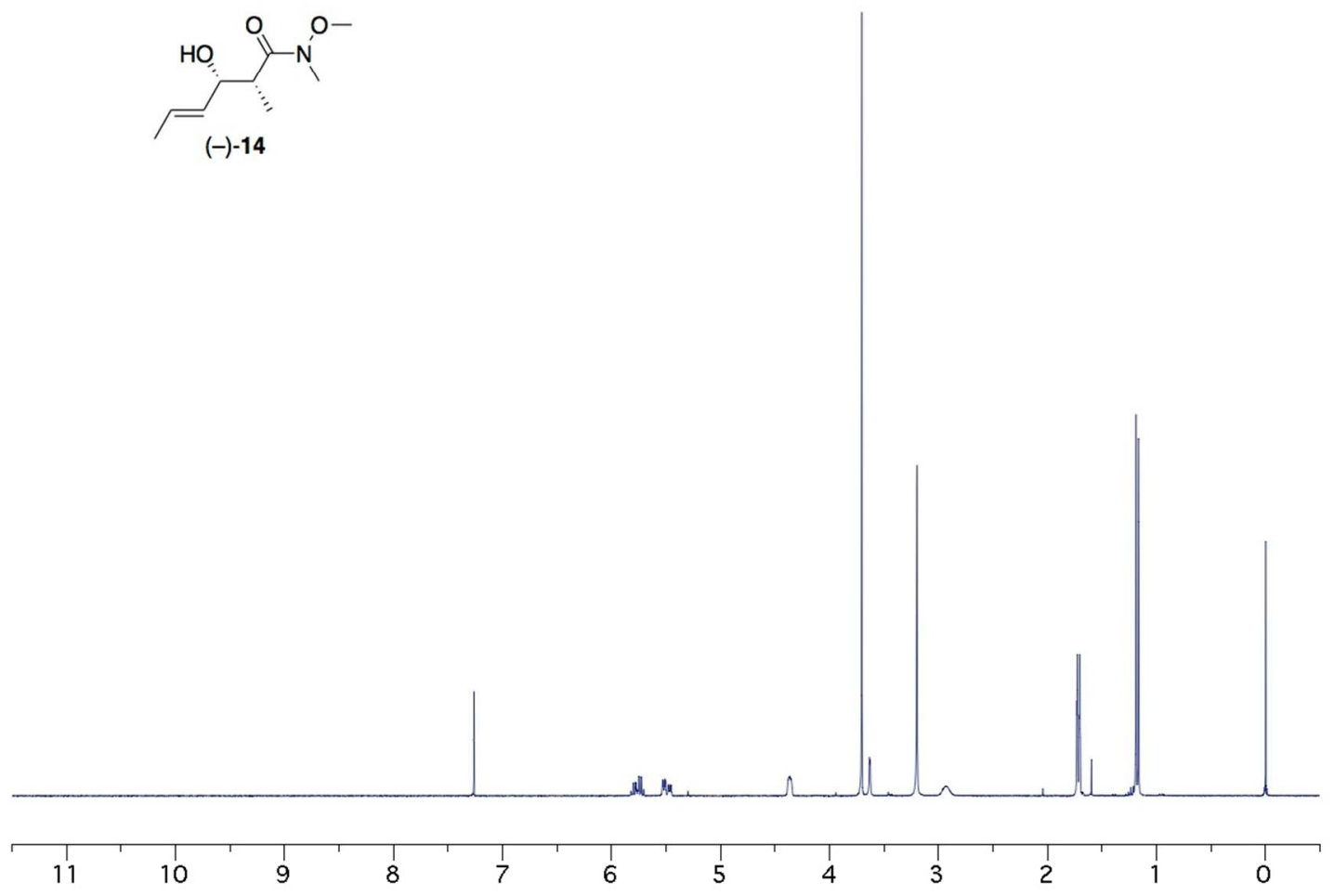



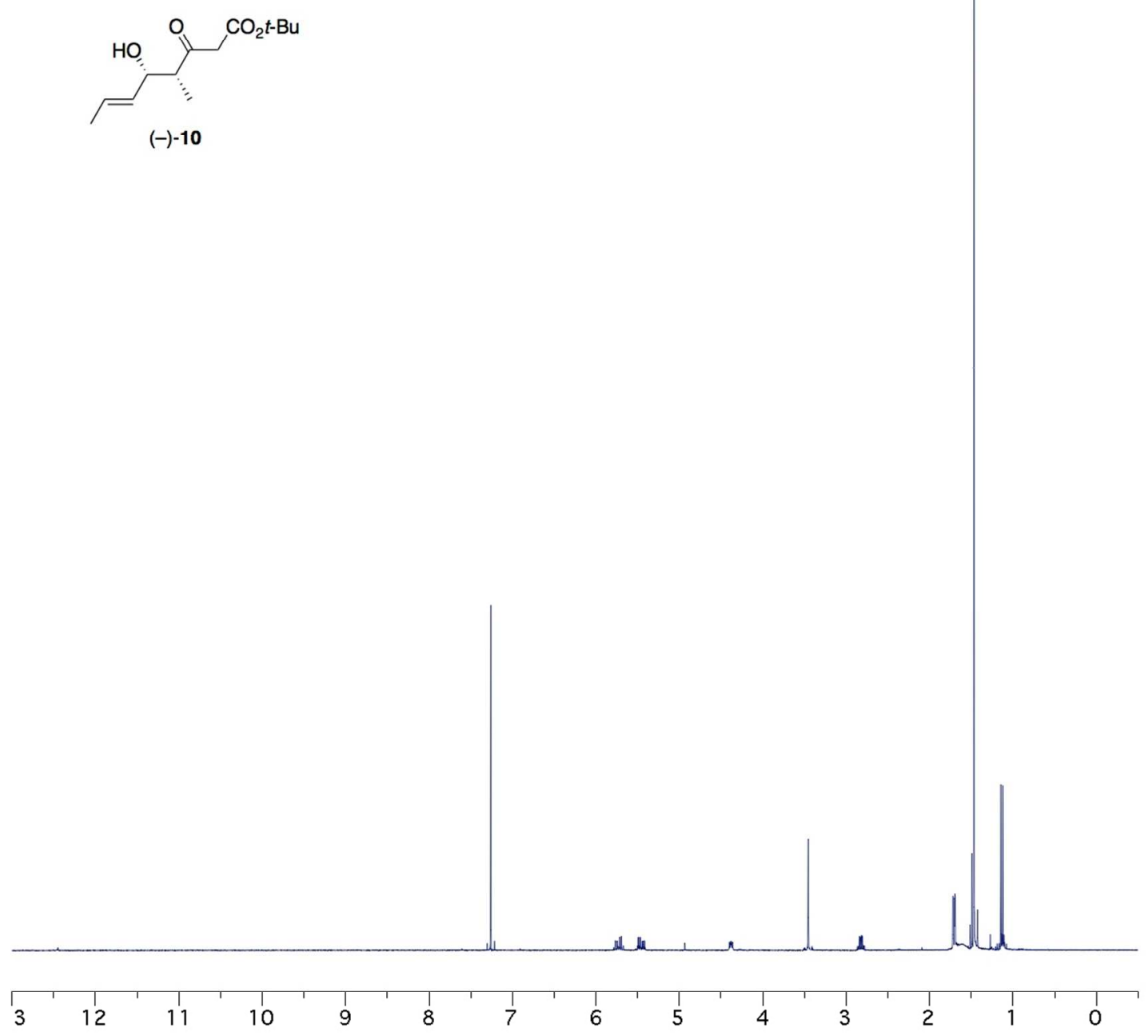

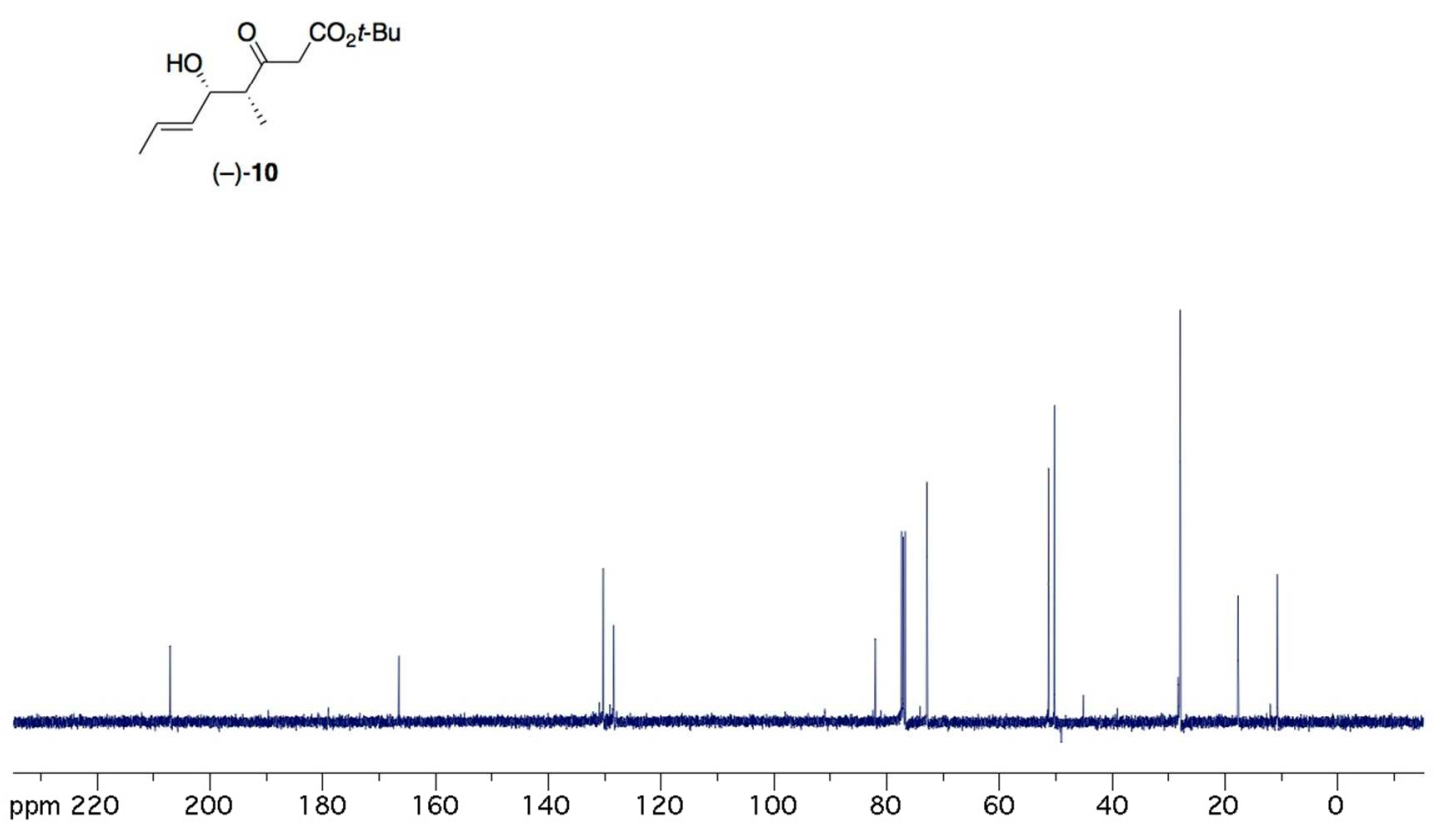

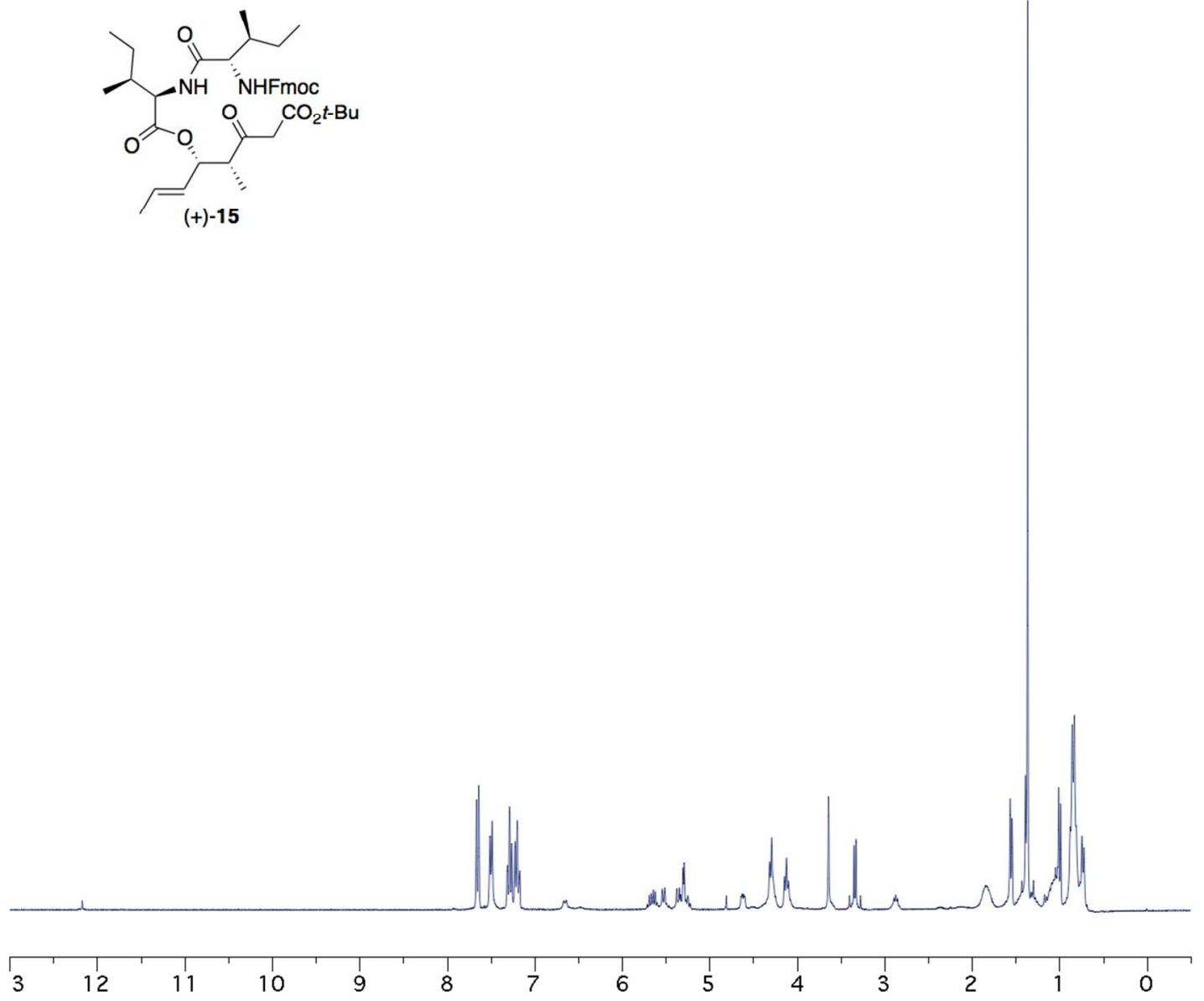


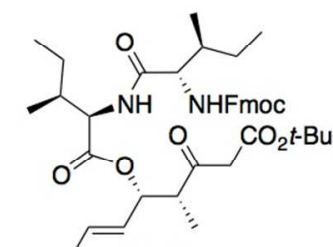

(+)-15

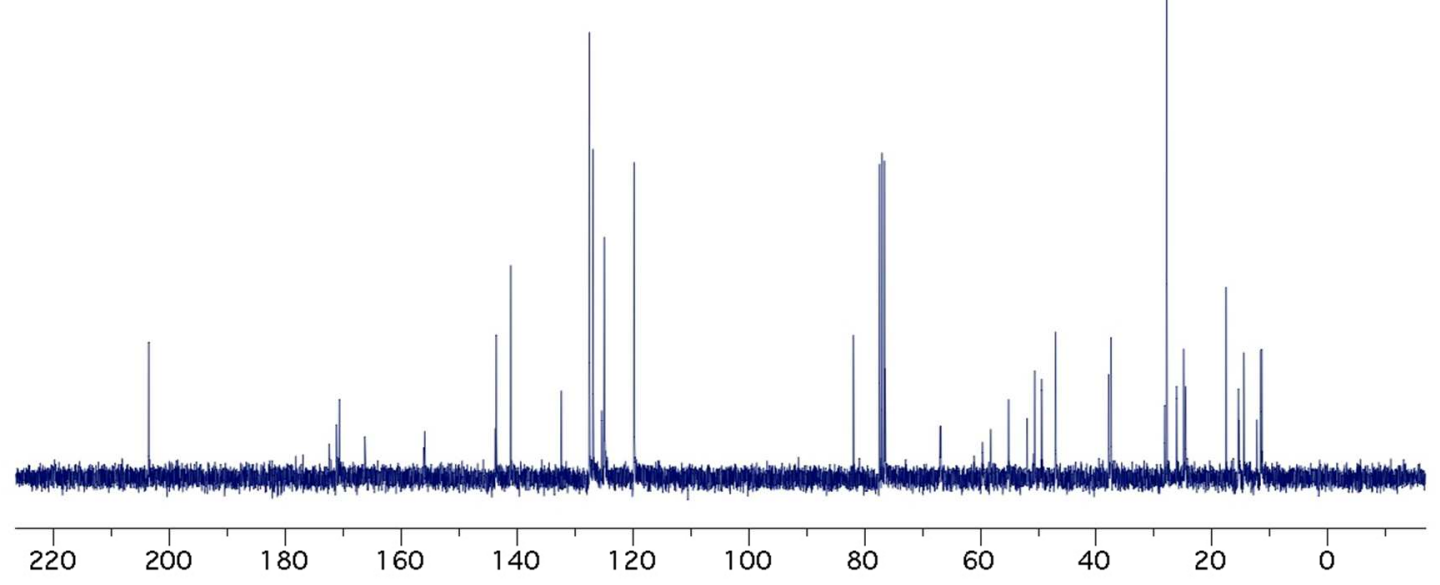



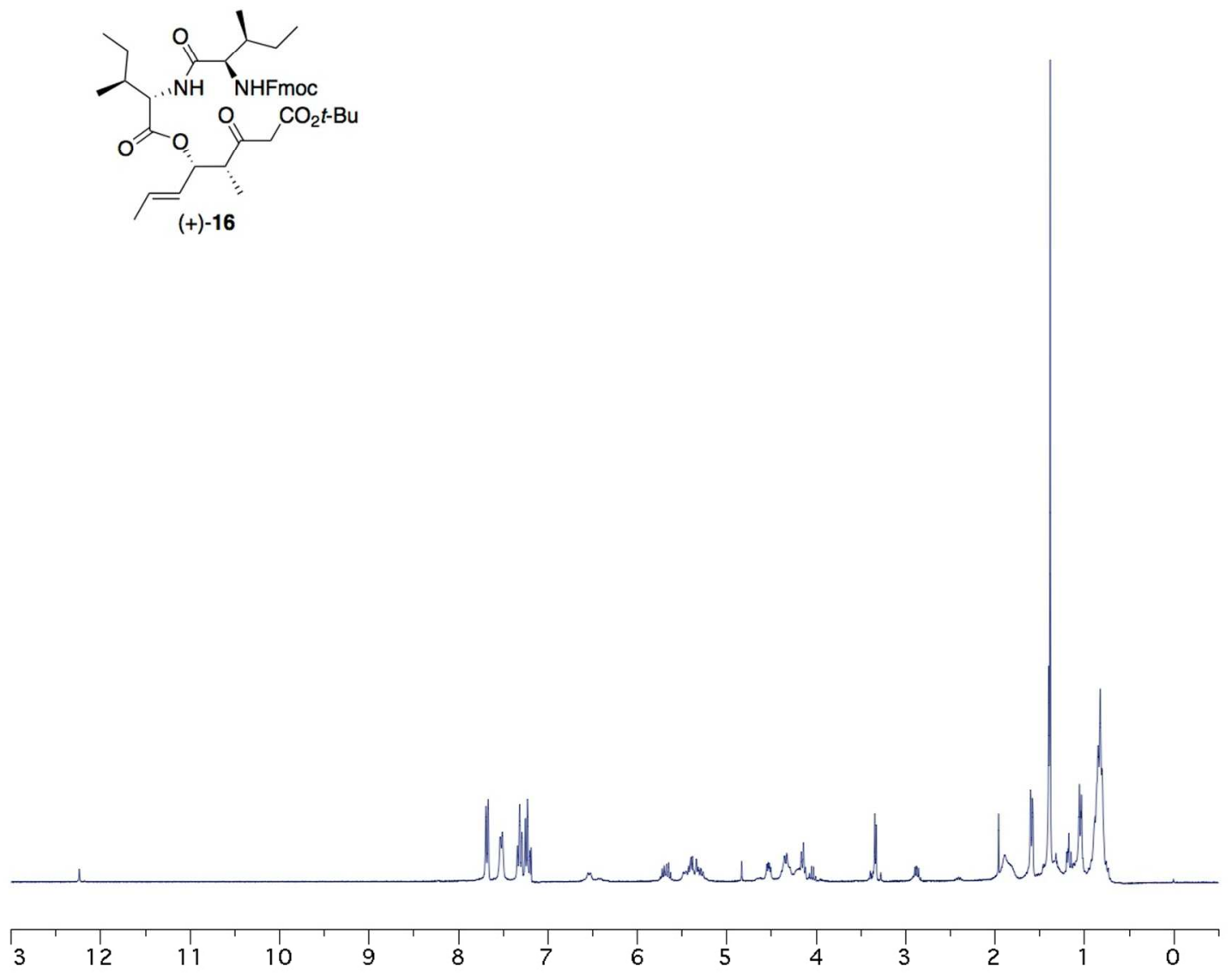

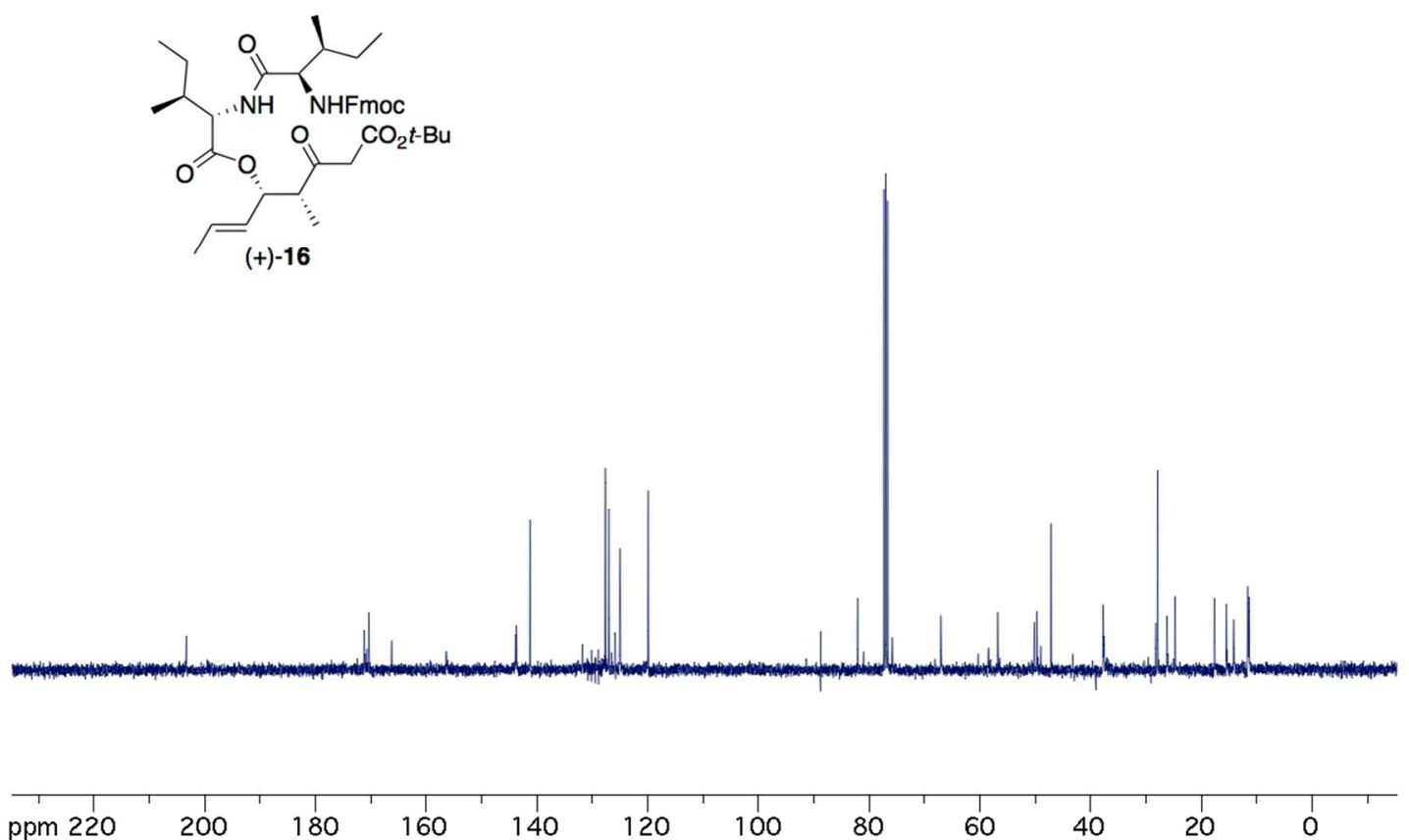


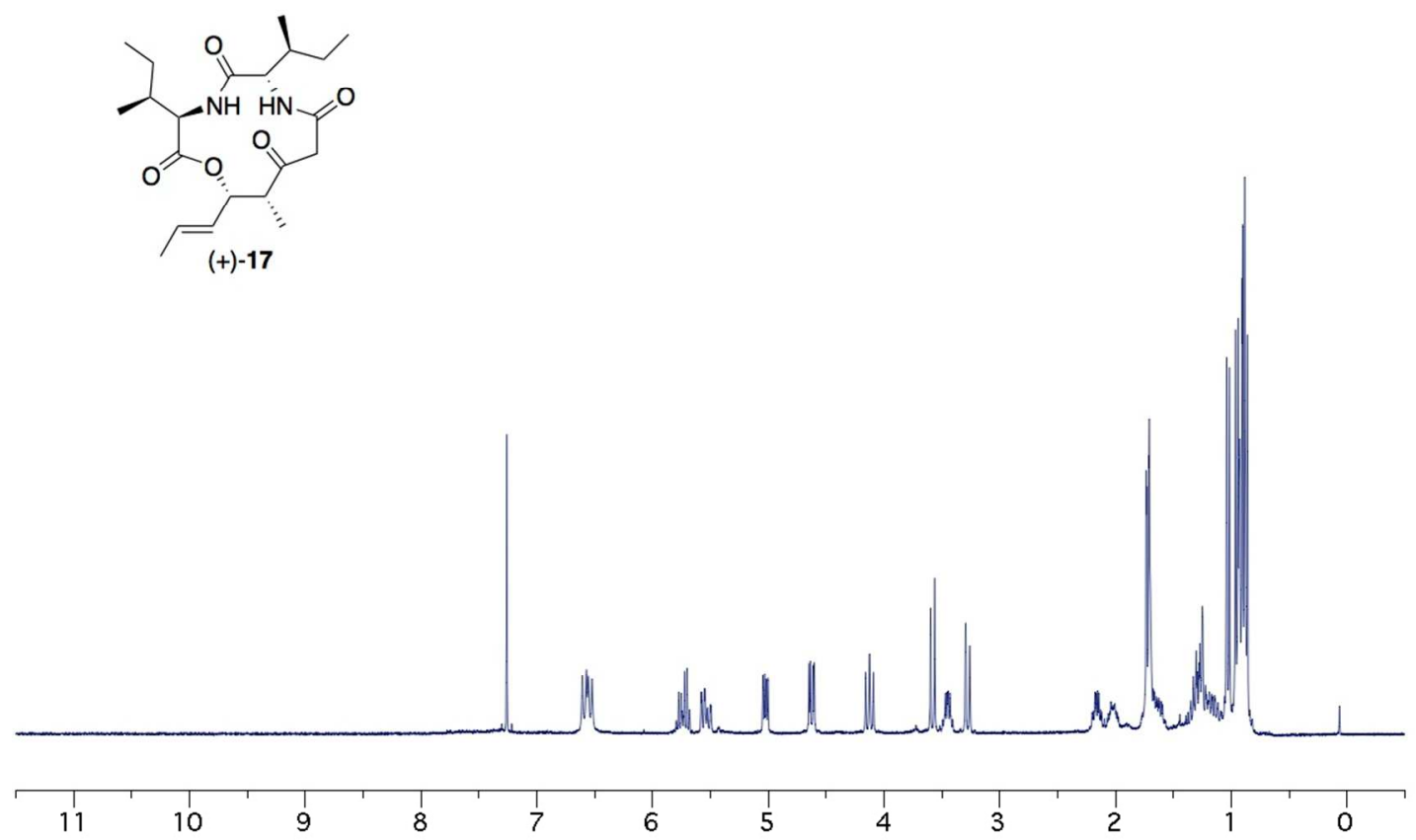




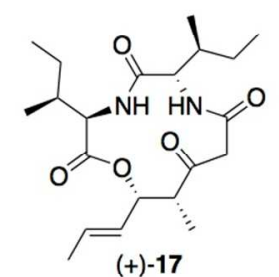

(+)-17

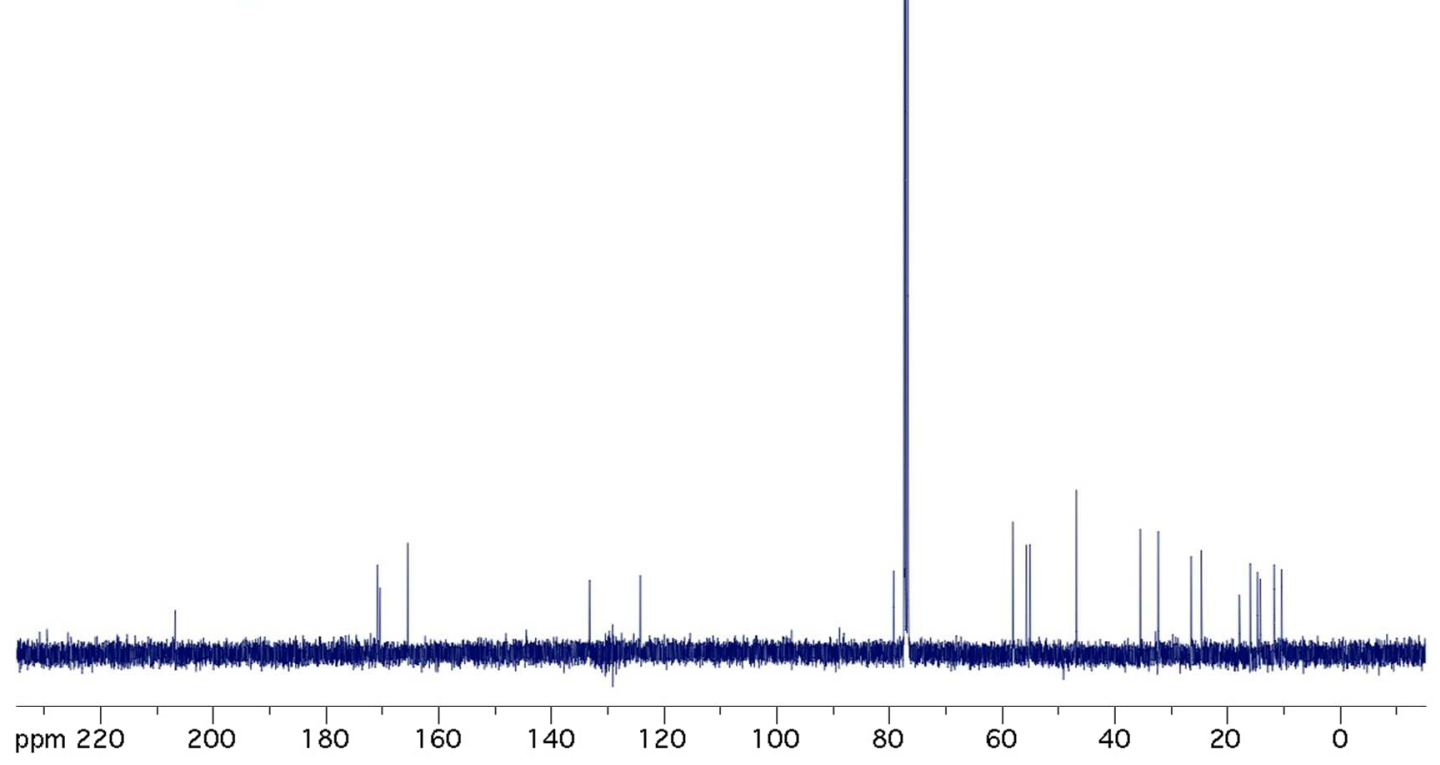



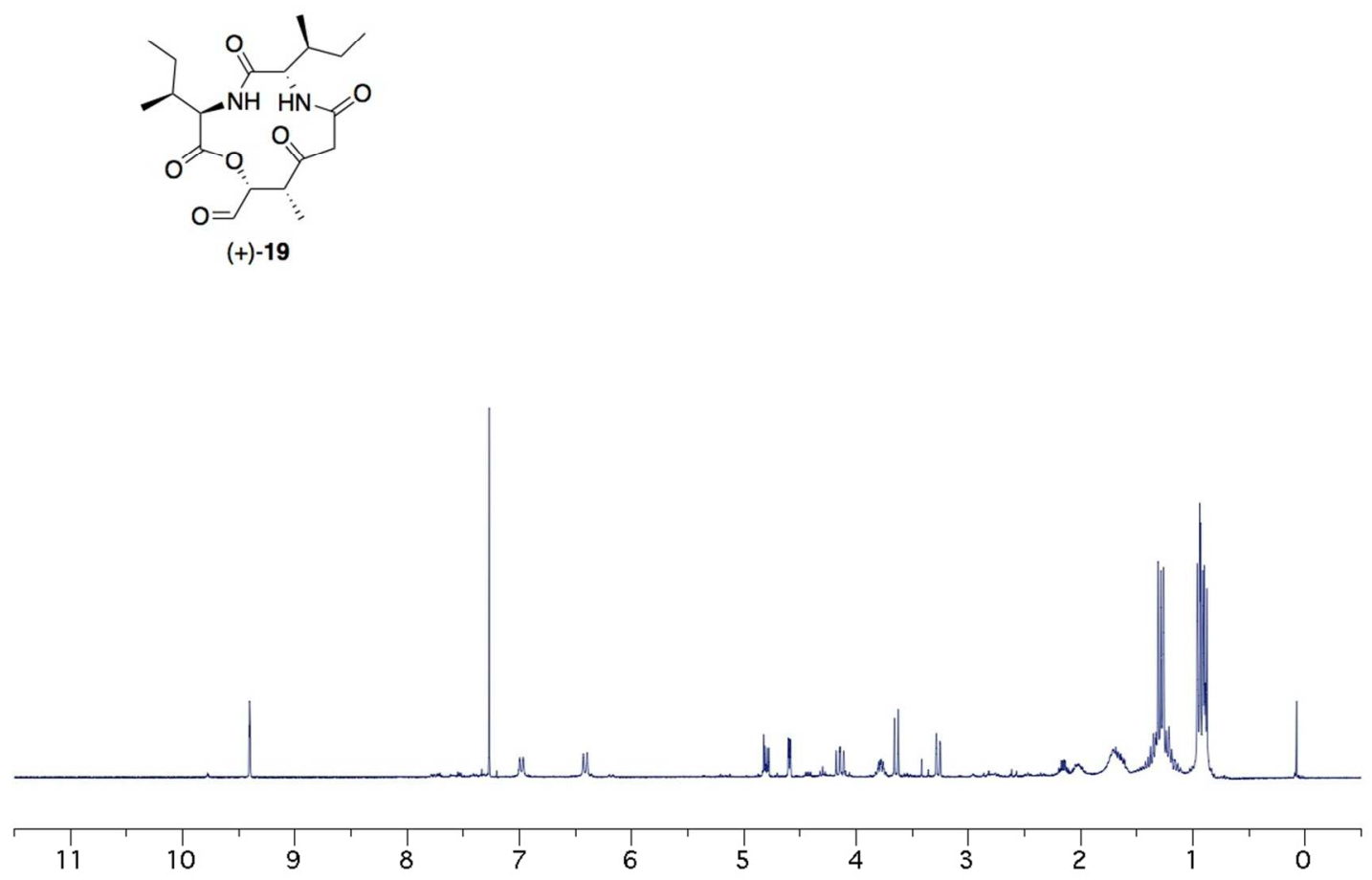


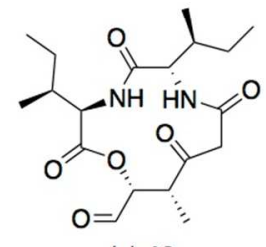

(+)-19

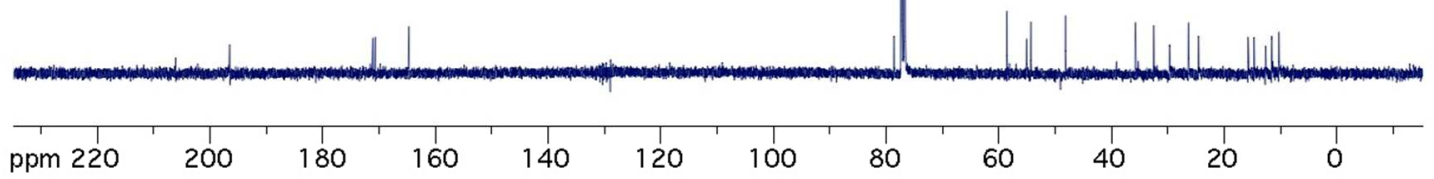




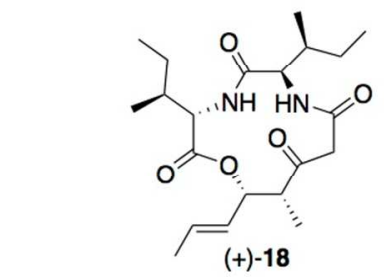




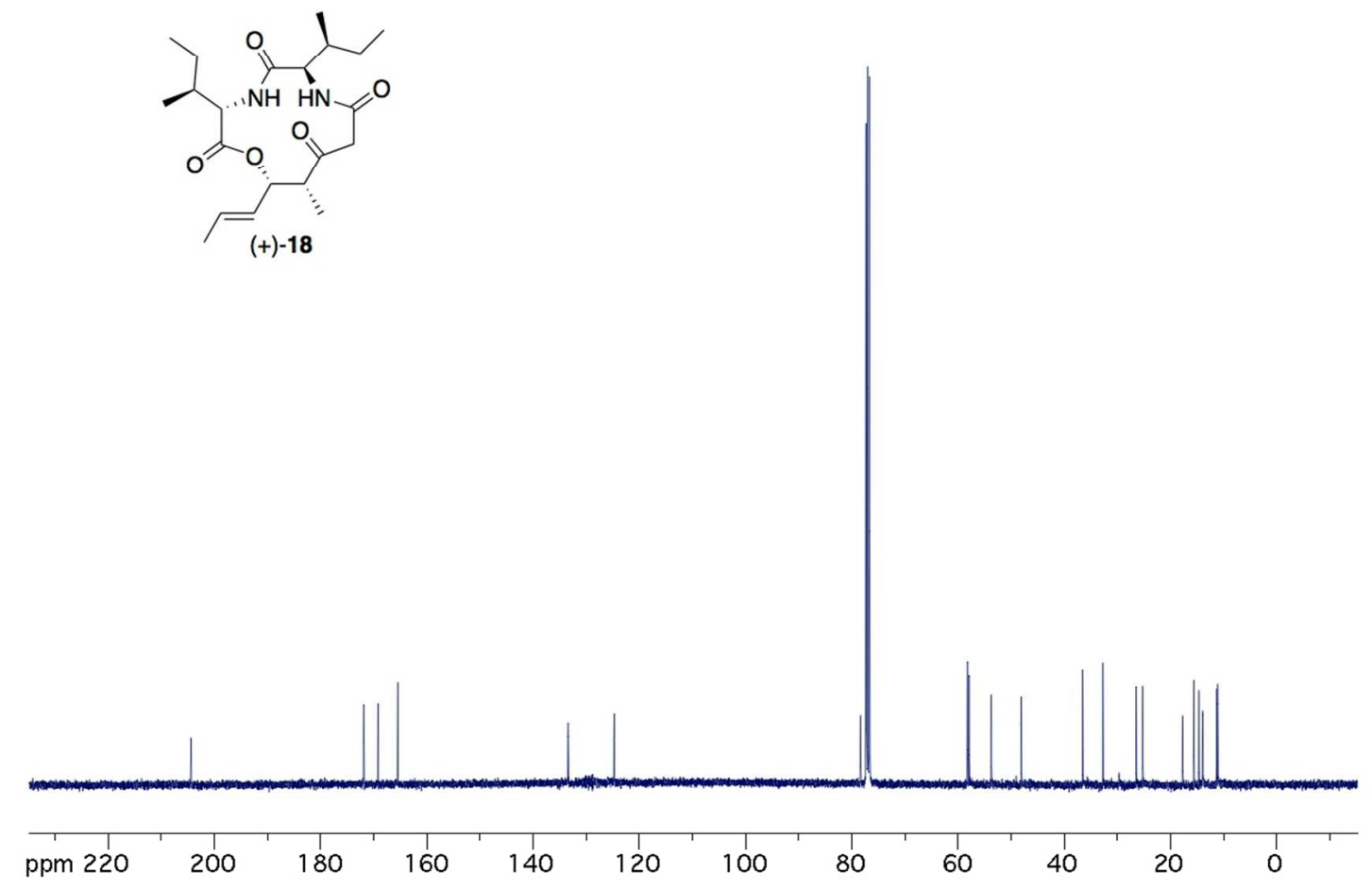




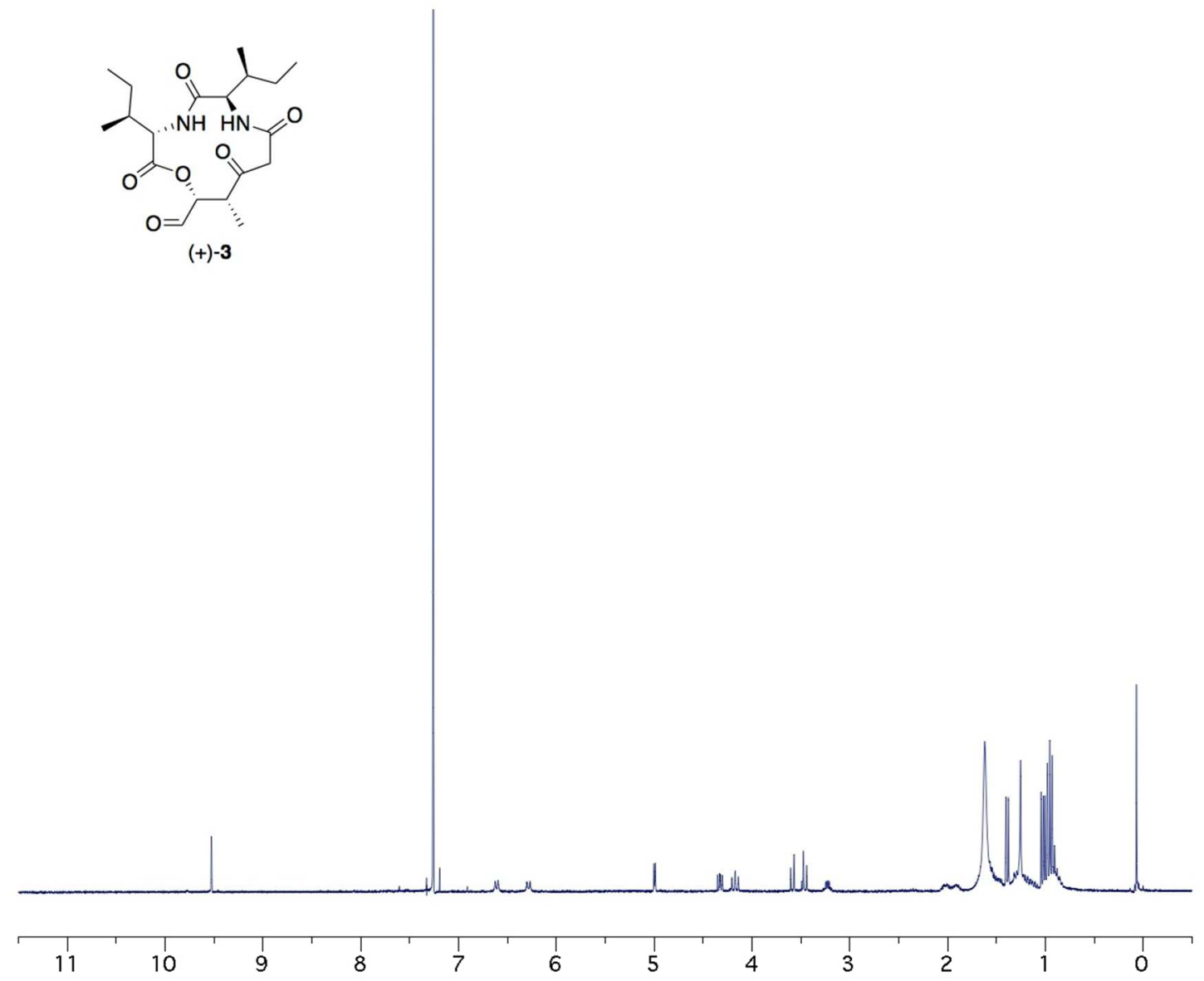




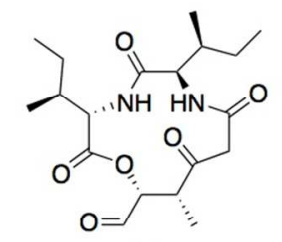

(+)-3

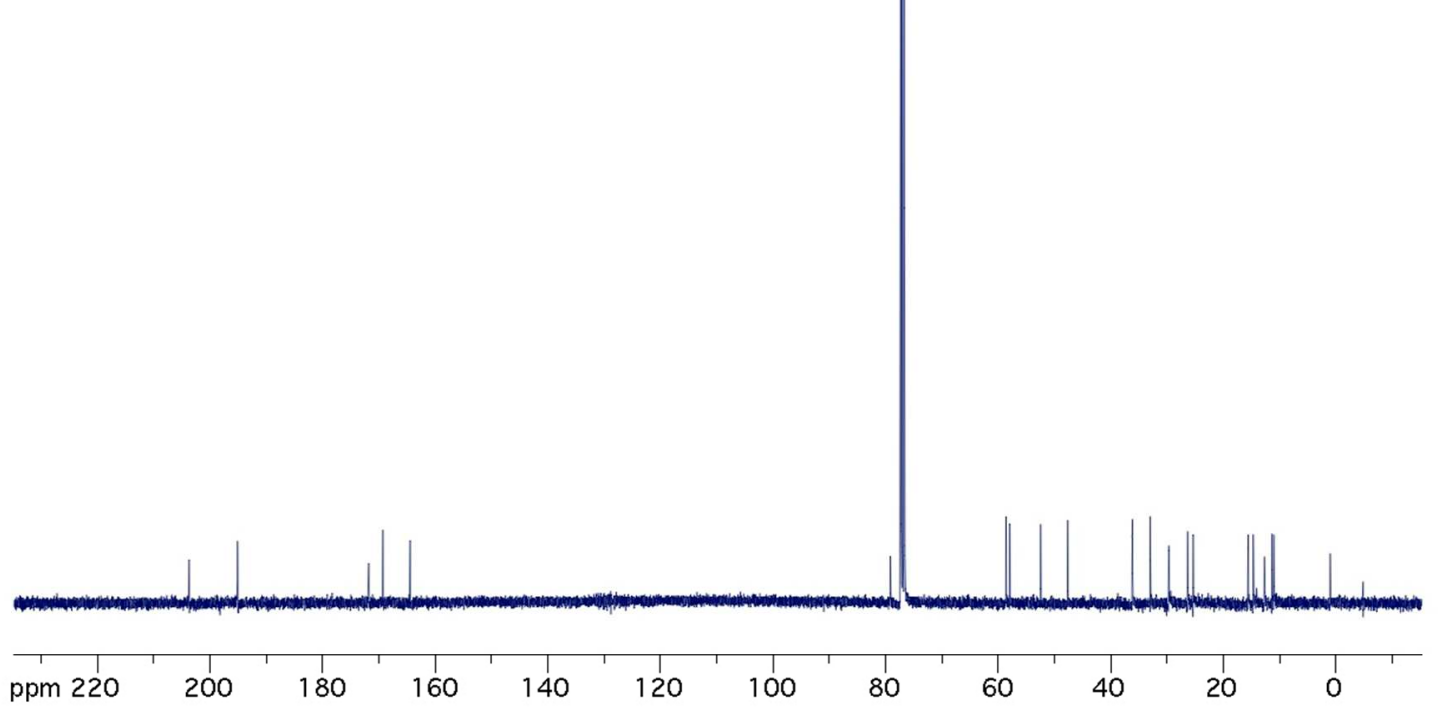




\section{${ }^{1}$ H NMR Comparison}
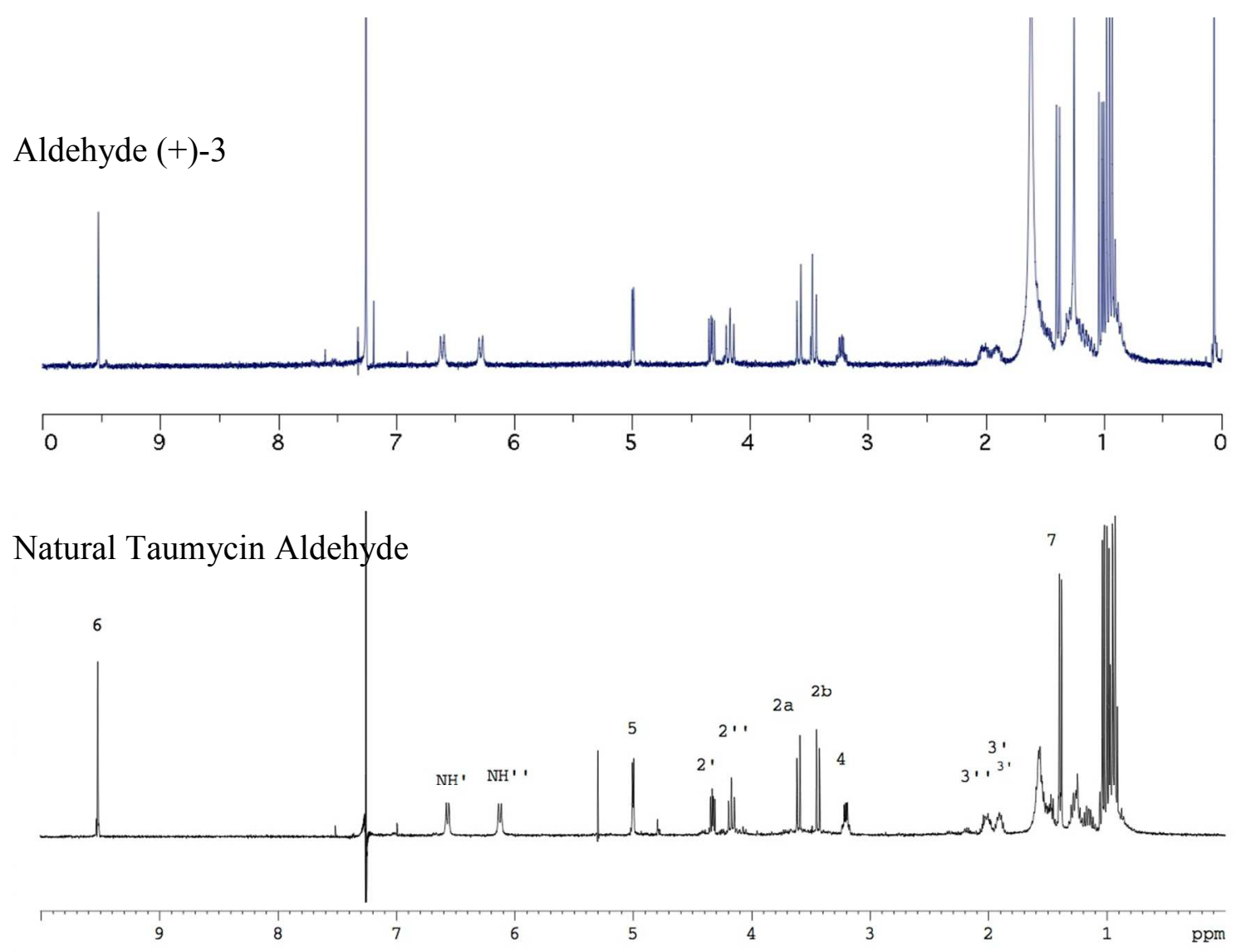